\title{
Gated communities: Sprawl and social segregation in southern California.
}

[Version: October 2004 (revised). - This paper is due to be published as LE GOIX R., 2004 (in press), "Gated communities sprawl in Southern California and social segregation», Housing Studies. Please do not quote without permission. First submission in October 2003 Part of an earlier version of this paper was presented at the International Conference on gated communities, Glasgow, September 18-19, 2003]

Summary.

Gated communities, which are walled and gated residential neighborhoods, represent a form of urbanism where public spaces are privatized. In the U.S., they represent a substantial part of the new housing market, especially in the recently urbanized areas. They have thus become a symbol of metropolitan fragmentation. This paper focuses on how local governments consider them as a valuable source of revenue because suburbanization costs are paid by the private developers and the final homebuyer, and how this form of public - private partnership in the provision of urban infrastructure ultimately increases local segregation. An empirical study in the Los Angeles region aims to evaluate this impact on socio-economic and ethnic patterns using factorial analysis (dissimilarity indices). As a result, the sprawl of gated communities increase segregation. Very significant socio-economic dissimilarities are found to be associated with the enclosure, thus defining very homogeneous territories, especially on income and age criteria. But gated communities are located in ethnic buffer zones and stress an exclusion that is structured at a municipal scale.

Keywords.

Gated communities, urban sprawl, segregation 


\section{Gated communities: Sprawl and social segregation in southern California.}

[Version: September 2004 (revised). First submission in October 2003 - Part of an earlier version of this paper was presented at the International Conference on gated communities, Glasgow, September 18-19, 2003]

\section{Summary.}

Gated communities, which are walled and gated residential neighborhoods, represent a form of urbanism where public spaces are privatized. In the U.S., they represent a substantial part of the new housing market, especially in the recently urbanized areas. They have thus become a symbol of metropolitan fragmentation. This paper focuses on how local governments consider them as a valuable source of revenue because suburbanization costs are paid by the private developers and the final homebuyer, and how this form of public - private partnership in the provision of urban infrastructure ultimately increases local segregation. An empirical study in the Los Angeles region aims to evaluate this impact on socio-economic and ethnic patterns using factorial analysis (dissimilarity indices). As a result, the sprawl of gated communities increase segregation. Very significant socio-economic dissimilarities are found to be associated with the enclosure, thus defining very homogeneous territories, especially on income and age criteria. But gated communities are located in ethnic buffer zones and stress an exclusion that is structured at a municipal scale.

Keywords.

Gated communities, urban sprawl, segregation

\section{Introduction}

Gated communities, which are walled and gated residential neighborhoods, have become a common feature in US metropolitan areas. Based on an empirical study in the Los Angeles region, this paper focuses on how gated communities, as a private mean of provision of public infrastructure, produce increased segregation at the local scale. It aims to trace the ways local governments usually favor the development of this form of land-use to pay for the cost of urban sprawl, while indeed producing social diseconomies for the whole metropolitan area. 
The social sciences literature about gated communities has been highly publicized, and three types of arguments are now part of a general theoretical discourse, which especially focuses on the relationship between gated communities and social segregation. First, gated enclaves are described both as a physical and obvious expression of the post-industrial societal changes (fragmentation, individualism, rise of communities), as part of a commoditization trend of urban public space (Sorkin, 1992; Dear, Flusty, 1998), and as a penetration of ideologies of fear and security supported by economic and political actors (Davis, 1990, 1998; Flusty, 1994; Marcuse, 1997). A second set of arguments presents gated communities as symptoms of urban pathologies, among them social exclusion is considered to be preeminent. Voluntary gating and the decline of public spaces in cities are seen as being detrimental to the poorest social classes (Blakely and Snyder, 1997; Caldeira, 2000; Glasze, Frantz and Webster, 2002). Finally, the rise of private enclaves is argued to be a "secession" by an elite opposed to the welfare redistribution system (Reich, 1991; Donzelot, 1999; Donzelot and Mongin, 1999; Jaillet, 1999), given the assumption that public provision of services is inefficient (Foldvary, 1994). The debate about gated enclaves and segregation has been lively despite a lack of empirical arguments to sustain it, as it is difficult to gather a representative sample of gated communities at a local scale.

This research derives from the above outline of arguments. It seeks to provide some evidences of the impact of these communities on segregation patterns within the metropolitan region of Los Angeles. To introduce how gated communities produce social exclusion, it is of interest to recall how developers usually design them as homogeneous social environment. The appeal of gated communities is inspired by the historical private estates found near industrial-era cities, such as Llewellyn Park near New York, associated with an anti-urban 
ideal (Castells, 1983; Jackson, 1985). Nowadays, gated enclaves are mostly commoditized suburban neighborhoods for the upper and middle class, emphasizing a "community lifestyle" (Blakely and Snyder, 1997). Their promotion typically focuses on sport and leisure amenities and family life. Furthermore, they are Common Interest Developments (CIDs), aiming to protect property values through design policies and Covenants, Conditions and Restrictions (CC\&Rs). Along with landscaping and architectural requirements, subjective criteria of social preference are common in many CIDs (McKenzie, 1994; Kennedy, 1995, Fox-Gotham, 2000; Webster, 2002), thus helping to maintain a homogeneous social pattern. Furthermore, CIDs are public actors because of the nature of their provision of a public service to the residents and their right to collect a regular assessment. They act at the same time as private governments, based on a private contract (CC\&Rs) enforced to protect property values (McKenzie, 1994; Kennedy, 1995).

But gated communities are far more than a regular CID. Excluding themselves from the public realm, gated communities are then referred to as a club (Webster, 2002). For the residents, all being members of the "club", gating a neighborhood can be conceived in a first instance as a pre-emptive attempt to protect the neighborhood. Residents are supplied with their own security, roads, amenities, etc., in a private governance effort to avoid the spillovers of urban residential and industrial developments: crime, increasing through traffic, free-riding of the amenities, urban decay and decreasing property values due to unwanted land-use.

I propose to analyze this preemptive protection of the neighborhood as being detrimental to the neighbors of a gated community and the adjacent urban communities. This proposition requires considering the broader theoretical context of the production of urban space in a capitalist city, and the genesis of the urbanization process within the capitalist mode of production. This can be described as a land-use system consisting in interpenetrating 
private and public spaces governed by complex patterns of property rights. These spaces are the outcomes of location strategies of actors considering "dense polarized differential locational advantages through which the broad social and property relations of capitalism are intermediated" (Scott, 1980). The capitalist production of urban space by private firms and homeowners, making individually optimal decisions, has a social cost and generates spillovers effects, such as pollution, sprawl, congestion, competition for land uses, land speculation, free-riding...Interpreted as a market failure (Bator, 1958), such externalities represent a cost for the society as a whole. Following this theoretical thread, gating a neighborhood can be conceived in a first instance as a private pre-emptive solution of market failures. It supplies the residents with their own private governance effort to avoid the spillovers of urban residential and industrial developments. On another hand gated communities also produce spillover effects on their neighbors, which this paper aims to address with a special interest for the impact on social patterns.

In this context, I assume that the specificity of gated communities does not derive from property-owners association status, a now dominant form of housing in the U.S. (McKenzie, 1994). It indeed relies on the physical border, which interacts with the territorial nature of the urban space. On one hand, access control and security features represent a substantial cost for the homeowner, not only for the cost of building the infrastructures, but also for their maintenance. On the other hand, the private access acts as a guarantee of the exclusive use of a site, which favors site rent and property value and creates a desirable place to live in (Le Goix, 2002). As a consequence, the question does not address the CID that lies behind the gate, but the effects of gating. Gating can then be analyzed as a border between several territorial systems: the systems of the city and adjacent neighborhoods versus the 
system of the gated enclave. This paper analyses the sprawl of gated communities in southern California, and evaluates its social impact. It is based on a methodology to assess the impact of gating over the social and ethnic patterns of residents, both inside the gated enclave and beyond the walls.

In a first part, a comprehensive study of the diffusion of gated communities in southern California leads to insights about the connections between gating and urban sprawl, since public governments tend to transfer the costs of urbanization to private developers. Socio-economic and ethnic spillover effects are analyzed in a second part. The demonstration of increased segregation associated with gating relies on a dissimilarity index and discontinuities mapping, which relevant methodology will be hereafter explained.

\section{Gated communities and urban sprawl}

The diversity of gated communities has to be taken into account, in order to assess the extent of the market accurately. Blakely and Snyder (1997) have identified three major types of gated communities: elite or golden-ghetto communities based on prestige, life-style communities where gates assure the exclusive access to leisure facilities, and "security zones communities" where safety is the main concern of residents and now including several lowend neighborhoods retrofitted with gates to promote their safety and control gang activities.

\section{The location of gated communities}

Because of the lack of a comprehensive survey of gated communities at a local scale, this research is based on a database derived from the same sources as a prospective homebuyer would use. Once integrated within a Geographical Information System with 2000 Census data, the diversity of the market can be assessed, as well as the location of gated 
communities, their social patterns and their impact. Accompanied by field surveys, interviews with gated communities and local officials, the most important sources for locating gated neighborhoods were Thomas Guides ${ }^{\circledR}$ maps plotting gates and private roads, real-estate advertisements in the press and in real-estate guides, and County Assessor's maps. 219 gated communities built before 2000 have thus been identified in 7 counties (Los Angeles, Riverside, Orange, Ventura, San Bernardino, Santa Barbara and San Diego).

Using the latest results from the 2001 American Housing Survey, Sanchez, Lang and Dhavale (2003) accurately estimate that $11.7 \%$ of the households are in walled, fenced and access-controlled communities in the Los Angeles Metropolitan Area, based on a national sampling of households. It is relevant to mention here that the research presented herein relies on a more restrictive sampling of gated communities, designed to exclude the condominiums and secured apartment complexes, as they do not include privatized public spaces, according to Blakely and Snyder's definition of gated communities (1997). Usually in vertical co-ops and condominium the common areas are limited to a parking lot, a shared garden or a swimming-pool, that does not meet the definition of public spaces (streets, places, sidewalks, parks, beaches).

\section{$<<$ INSERT FIG. 1 ABOUT HERE $>>$}

Figure 1. The size and location of gated communities in southern California.

For the sample of gated communities for which the size is accurately known (Figure 1), the number of dwelling units located behind gates in 2000 can be estimated to 80,000 (an estimate of 230,000 inhabitants), or $1.5 \%$ of the housing stock, and increasing at a fast pace. In 2001, according to the New Home Buyers Guides, this market represented a $12 \%$ average of the new homes market in southern California, but $21 \%$ in Orange county, $31 \%$ in San Fernando Valley and $50 \%$ in the desert resort areas of Palm Springs. 
Three factors explain the location of gated communities. First, their locations tend to maximize location rents. Ocean fronts in Santa Barbara, Malibu, Newport Beach or Dana Point in Orange county, secluded hill areas in Palos Verdes peninsula or in Malibu Mountains, and finally desert and resort sites (Palm Springs) are the favorite locations.

Second, as most of the leisure-oriented residential developments use a large amount of space, the availability of land is an important factor. Leisure facilities and amenities indeed consume a lot of space, and both developers and residents favor large individual lots clustered in a surrounding setting of large open space. Every large gated community such as Leisure World (19,000 inhabitants and 6 clubhouses) and Canyon Lake (9,000 inhabitants), as well as seven gated neighborhoods of more than 1,500 housing units in Palm Springs, are lifestyle communities or retirement communities located in remote setting favoring scenic views and the intimacy of residents. The secluded and oasis locations serve the same goal than the gate towards isolation from the urban social context.

Smaller gated communities are clustered near the central places of the urban region, in the north of Los Angeles County (West Los Angeles, Burbank and San Fernando Valley), in Irvine and Anaheim in Orange County or in the western side of San Bernardino County (Chino and Ontario). Some of them are former open neighborhoods, which have opted for the gating, like Fremont Place or Brentwood Circle on Sunset Boulevard (Moore, 1995a; 1995b). But small gated communities are often in-fill developments of vacant land in older urbanized areas, as the upper scale community of Manhattan Village (520 housing units) in Manhattan Beach, or the new middle-class communities named Stonegate (57 housing units) and Lori Lane (40 housing units) by Kaufman \& Broad in Anaheim and Garden Grove.

Finally, location is driven by the social environment. It is assumed that gated communities are tailored to fit to specific prospective buyers and located within a consistent 
social environment. A former study showed that gated communities are located within every kind of middle class and upper-class neighborhoods, and are now available for every market segment (Le Goix, 2002): half of them are located within the rich, upper-scale and mostly white neighborhoods, and one third are located within the middle-class, average income and white suburban neighborhoods. As an evidence of the social diffusion of the phenomenon, $20 \%$ of the gated communities surveyed are located within average and lower income Asian or Hispanic neighborhoods, especially in the northern part of Orange County and in the North of San Fernando Valley.

\section{A diffusion of gated communities according to suburban sprawl patterns}

The spatial distribution of gated communities is linked with the urban sprawl. A chronological cartography (Figure 2) of four different stages shows evidences of a diffusion process within the Los Angeles region. Each map describes the situation at a date when important change occurred in the Los Angeles development. The first gated neighborhoods were developed in 1935 in Rolling Hills and in 1938 in Bradbury, and some well known gated communities were built early after World War II, like the upper-scale Hidden Hills (1950), and the original Leisure World at Seal Beach (1946) housing veterans and retired in Orange county. Before 1960, about 1700 housing units were gated in the Los Angeles area, then increasing up to 19,900 in 1970 , because of the developments of major gated enclaves like Leisure World (1965) and Canyon Lake (1968). After 1970, the new developments were smaller than they used to be in the 1960s, and the growth rate decreased: 31,000 gated units in $1980,53,000$ in 1990 and 80,000 in 2000.

The diffusion pattern of residential homogeneous suburban communities is related to the suburban growth, an anti-fiscal posture, and the municipal fragmentation dynamic that 
have affected the Los Angeles area since the 1950s. In Los Angeles, this trend has been motivated by an anti-fiscal posture, by the mean of municipal incorporations as the Lakewood residential development first experienced when it became an autonomous city in 1954. Many municipal incorporations were designed to avoid paying the costly county property taxes while charged a lower assessment by the city and getting a better control over local development (Miller, 1981). A second diffusion step came with the 1978 "taxpayers' revolt", when homeowners became the driving force for a property taxes roll back known as Proposition 13 (Purcell, 1997). Meanwhile, the tax limitation was increasing the need for public governments to attract new residential developments and wealthy taxpayers under their jurisdictions, thus supporting gated communities as perfect "cash cows" (McKenzie, 1994). A third spatial diffusion pattern of gated enclaves is connected with the trend of rapid growth in southern California, sustained by massive population flows driven to the Sun Belt cities during the 1980's (Frey, 1993).

\section{《 INSERT FIG. 2 ABOUT HERE $>$}

Figure 2. The diffusion of gated communities in southern California.

According to figure 2, three diffusion processes of gated communities have occurred in the area:

- a diffusion by contact between zones where gated communities were previously developed. Hidden Hills in the western part of L.A. county, Eldorado (1957) in Palm Springs and Indian Wells, or Niguel Shore (1975) in Dana Point played a key role as local landmark, soon surrounded by other gated enclaves imitating them; 
- preferred locations are where site rental is maximized, explaining the multiplication of life-style communities favoring sea-side locations (Santa Barbara county, Dana Point, Newport Beach...);

- a diffusion outlining the polycentric pattern of edge-cities, with clusters of gated communities near areas like South Orange county and its dynamic high-tech economy in Irvine, as well as in the San Fernando valley and Burbank. These dynamic technopoles provide a massive flow of potential buyers. Large urban private developments such as Irvine being designed as innovative privately operated communities, although supported by public authorities (Garreau, 1991; Forsyth, 2002), it is not surprising to find gated communities in such an environment of mixed governance.

\section{A diffusion based on a public-private partnership}

Most gated communities were built within unincorporated areas, but some have since incorporated as their own municipalities like Bradbury and Rolling Hills in 1957, Canyon Lake in 1991, Leisure World in 1999 (Le Goix, 2001), or as a part of a new city. For example Dana Point incorporated in 1989, Calabasas in 1991, where a substantial part of single-family housing developments is gated. Although the municipality acts as an extension of the Property Owners Associations, the arguments for the incorporation pointed out the desire to control the local land development, and to challenge the trend of the County Board of Supervisors to support new residential subdivisions. Calabasas incorporation in 1991 is representative of such issues, as the new developments are all gated. Gated communities in the Calabasas Park subdivision challenged in 1987 an extension of 2,000 units on unincorporated land, while pushing for the incorporation. As the incorporation had previously 
failed several times, homeowners became suspicious that the County Board of Supervisors might try to push for new developments, while the Local Authority Formation Commission (LAFCO) was slowing down the incorporation. The incorporation process went back and forth during 11 years, while the County had already approved 4,500 new units (Pool, 1987a, 1987b, 1987c; Kazmin, 1991a, 1991b).

Calabasas is a good example of the ambiguous relationships between the public authorities' interests for developing gated communities, and the private homeowners willingness to live in a secluded and controlled place. Gated communities basically are Planned Unit Developments (PUD), implying that the developer substitutes the public government in planning and buildings roads, access and utilities lines (Knox, 1997). As stated in the California Subdivision Map Act (Sections 66410 et seq.), the public authority has jurisdiction to regulate and control the development of the project in a subdivision. Once the tentative maps accepted and the subdivision authorized, the builder replaces the public authority. In the case of Master Planned Communities, such a substitution is comparable to a private provision of public services (McKenzie, 1994), as the developer is required to finance the infrastructures, landscaping and improvements to ensure the consistency of the development with any applicable general plan (Curtin, 2000, p. 83). As a consequence, the overall cost of urbanization is transferred to the private developer, who consequently makes the final buyer pay for those infrastructures when ultimately purchasing his property. Other tools are also available to transfer the urbanization costs to the final homeowner, instead of the general taxpayer having to pay for them. Such tools encompass the "developers fees" paid by a developer to the public authority to cover the public services improvements needed by every additional units. The developer may alternatively be required to set aside a certain amount of free land, which can be used to build a school or a library once ceded to the public authority. Last but not least, a Community Facility District (a costly special assessment on 
every properties located within their boundaries) can be created to transfer the cost to the local homeowner instead of charging the general taxpayers (Brown, 1991).

These transfers of urbanization costs to the homeowner are outlining the interest of gated communities in the urban planning process. Because of the gate, no public money can be spent within the gates, otherwise the public access to any public-owned facility located inside the community would be granted and the gates would eventually become useless and fail achieve their goal. Such issues are documented by the 1992 decision of Hidden Hills to build its city hall outside its gates in order to allow public access (Ciotti, 1992; Stark, 1998). The 1994 Citizen's Against Gated Enclaves (CAGE) vs. Whitley Heights Civic Association case banned the gating of public streets (Kennedy, 1995). In 1999, Coto de Caza rejected a project to build a public school within its gates because it would have allowed public inside the gated community (N'Guyen, 1999). As a consequence, no public money can be spent for the maintenance of the private roads since they are gated.

Indeed, gated communities development results of a market demand for security features fitting a standardized leading offer from the homebuilding industry, but also emerges from a partnership between local governments and private land developers. Both agree to charge the final consumer (i.e. the home buyer) with the overall cost of urban sprawl, since he will have to pay for the construction and the maintenance of urban infrastructures located within the gates. As compensation, the homebuyer is granted with a private and exclusive access to sites and former public spaces (for example the Lake in Canyon Lake, which is originally a public property leased to the association). Such exclusivity favors the location rent, and can positively affect the property value. On the other hand, it provides the public authorities with wealthy taxpayers, thus considering gated communities as property taxes “cash cows” (McKenzie, 1994). 


\section{Assessing the impact of gated communities on social segregation}

Given the ambiguous relationships between public authorities and gated communities favoring the sprawl of a peculiar form of urbanism, the question is then: How does this affect segregation patterns? As previously mentioned, the private governance and the implementation of restrictive covenants lead to an implicit selection of the owners, through design guidelines, age restrictions or a selective club membership, in order to insure the homogeneity of the neighborhood. Access control features reinforce this construction of exclusion, as one can be only from the inside, or from the outside. The following hypothesis can thus be formulated: the gating and the exclusiveness create a border. The border separates two spatial systems: the territorial system of the gated community, and the urban space where it is located. It is assumed that the act of gating worth its cost, and that it has an effect over the social patterns, the property values, etc., thus making gated communities a desirable residential environment to live in.

\section{The impacts of gating}

Accordingly, gated communities should differentiate from their immediate vicinity, from which homeowners are trying to protect themselves against negative spillovers (crime, property value decay...), hiding behind gates. However, because the erection of a border implies a two-way relationship between the two adjacent territories, gated communities also produce externalities over their neighbors. Such issues have already been discussed with regards to crime and property values patterns. As the motivations for living in a gated community are mostly driven by the fear of crime and fear of differences (Low, 2001), scholars have studied the impact of gating, although limited by the lack of empirical data. For instance, Helsley and Strange (1999) theoretically demonstrated that gating leads to a 
relocation of crime outside the gates and within adjacent non-gated communities. Studies were conducted assessing the effect of gating over property values. They demonstrated the protection of gated property values (Lacour-Little and Malpezzi, 2001; Bible and Hsieh, 2001), and the deterrent effect on property values in adjacent communities (Le Goix, 2003).

Herein lies the most well known effect of gating: its negative impact on property values in non-gated adjacent neighborhoods, and the theoretical crime redistributions. Such diseconomies may lead to a preventive proliferation of gating in the neighborhood, and former non-gated communities may have to retrofit with gates if they wish to maintain their property values, and avoid crime redistributions, thus explaining the clustered diffusion pattern previously exposed.

Beside crime and property values, it appears necessary to also address the social externalities of gating. This can be achieved to a certain extent by measuring how homogeneous gated communities can be compared to their neighbors, and on which criteria they differentiate from their vicinity. I propose a method to evaluate the level of socioeconomic differentiation occurring where gated communities are present. This is used in order to estimate the effect of gating over social segregation, relying on the following assumption: If the overall differentiations occurring between gated enclaves and their vicinities are higher than the differentiations usually observed in the urban area between two adjacent neighborhoods, then there is a high probability that gated communities indeed produce increased segregation.

\section{The discontinuity as a geographical concept}

For that purpose we define the discrepancy between a gated community and its vicinity as a discontinuity, in order to focus on whether a higher degree of social 
differentiations occurs where gates and fences are erected. In its broader definition, a discontinuity is what separates two adjacent spatial systems (Brunet, 1965). Close to the notions of border and barriers, the notion of discontinuity was used to study the differentiation processes produced by national borders on demographic patterns (Decroly and Grasland, 1992; Grasland, 1997). Discontinuity is a useful concept because it does not only address the ideas of separation (as a barrier) and segregation, but it allows to describe urban spaces in terms of differentiation processes produced by - or producing - physical barriers (François, 1995).

\section{Methodological concerns}

The effects of gating on segregation patterns are however difficult to evaluate for three reasons. First, it shall be assumed that social patterns in gated communities are almost consistent with their neighborhood, in order to insure the attractiveness of the development for potential buyers. As a consequence the method seeks to sort out the effects of walls and gates on each social characteristic (age, race, economic status). It relies on a multivariate analysis and clustering to test whether a gated community boundary fits any sensitive shift in the statistical definition of social areas.

Second, the implementation of this test relies on a function of the adjacency between census areas. As not properly addressed by the classical segregation or concentration indices (Apparicio, 2000), it has been necessary to use a dissimilarity index (Decroly and Grasland, 1992; François, 1995). The dissimilarity index equals the difference between the two contiguous areas $i$ and $j$ on a continuous factor $\mathrm{X}$. The factor $\mathrm{X}$ is extracted from a factor analysis, and describes the relative position of each area on a factorial axis produced by the joint effect of independent variables (Principle Component Analysis). A discontinuity appears where a significant level of dissimilarity between two contiguous census areas occurs. It may 
then be mapped as a segment materializing the level of discontinuity, and compared with gated communities boundaries layout.

Third, no direct answer can be provided about the level of discontinuity. The analysis is processed at the census block group level, the smallest geographic level where $100 \%$ sample data were available. But the shape of census geographical definition does not systematically match the boundaries of gated communities (Le Goix, 2002). This is a severe limitation in spatial analysis since only 30 gated communities exactly fit one or more census block groups (case A). The location of a gated community within a larger block group is a common case (case B). It is also possible to find several gated communities along with other regular neighborhoods within a single block group. In order to proceed despite this limitation, three different kinds of vicinity levels were defined, given that a segment is a line materializing the topological contact between two block groups (Figure 3):

- A first vicinity level applies to the segments between a gated community and its immediate surrounding, where block groups and gated communities definition perfectly fit each other (case A). In this case, this vicinity level will account for the discontinuities associated with every large gated community (basically, every large gated community housing more than 1500 inhabitants).

- A second vicinity level characterizes the dissimilarities observed in the environment where a gated community is located. It is in fact interesting to test whether the stronger discontinuity is produced by a gated community or by its surrounding neighborhoods. The latter means that a gated community might be surrounded by a very homogeneous social or ethnic buffer zone. This level is defined both by the segments in contact with block groups adjacent to the precedent level (case A), and by the segments of any block group where a small gated community is located (case B). 
- Finally, in order to set a comparative framework, a third vicinity level comprehends every segment observed between each 12,549 block groups of the area covered by the database. The evaluation of the segregation level at the local scale can then be analyzed everything being equal compared to dissimilarities observed in the whole metropolitan area.

\section{$<<$ INSERT FIG. 3 ABOUT HERE $>$}

Figure 3. Three vicinity levels around gated communities.

\section{Assessing the level of discontinuity}

Three main characteristics of the socio-economic differentiation are analyzed, using the following variables for each block group of the Los Angeles region:

- Socio-economic status: median property value 2000; owner-occupied housing units (\% of housing units 2000),

- Ethnicity: White persons; Black persons; Hispanic origins; Asian origins; Native American origins (\% of population 2000),

- Age: less than 18 years old; $18-24$ y.o.; $25-44$ y.o.; $45-64$ y.o.; more than 65 y.o. (\% of population 2000).

The factorial analysis demonstrates the high level of social separation in the Los Angeles area, with 2000 census data. The first axis (explaining $33.5 \%$ of the total variability) describes the ethno-linguistic oppositions and the related effects of age and status: white, aged and wealthy neighborhoods are opposed to the young, Hispanics and modest neighborhoods (Figure 4). A second factor (13\%) isolates the effect of life cycles and status, and thus opposes neighborhoods with young 25-44 years-old residents to owner-occupied and families with young children neighborhoods. A third factor (10.9\%) describes the sole effect of ethnic 
segregation, while it opposes Black and Asian neighborhoods to the mostly White areas, everything being equal regarding the social status. A fourth dimension $(9.7 \%)$ describes the differences explained by the age, everything being equal regarding the status. Young and middle-aged areas are opposed to very homogenate neighborhoods, inhabited by senior citizens, or by high concentration of 18-24 years old (campus and military housing), indeed lying behind another kind of gates.

\section{< INSERT FIG. 4 ABOUT HERE $\gg$}

Figure 4. Gated communities and the first socio-economic factor of segregation (South Los Angeles, Orange county and west Riverside county). $N B$ : Because of the size of the original maps and edition constraints, only part of the maps are published here.

A factorial axis being a continuous scale, it allows a comparison of the relative position of block groups. For each segment between two adjacent block groups, the difference between the coordinates on each axis was calculated. Considering the absolute value of the dissimilarity indices, the higher the absolute value is, the stronger the discontinuity.

\section{The local increase of segregation}

< INSERT FIG. 5 ABOUT HERE $\gg$

Figure 5. Major socio-economic discontinuities occurring in the vicinity of gated communities (South Los Angeles, Orange county, and west Riverside county).

The map (figure 5) provides qualitative information regarding the shape of the discontinuities, under the assumption that a continuously shaped discontinuity outlines an independent territorial system, whereas a poorly shaped discontinuity would only outline a subsystem included within a larger territorial system (i.e. a municipality). Where the shapes of discontinuities are simple and circumscribe the walls, it clearly demonstrates that gated communities actually build a specific territorial system within their urban environment 
according to a social singularity. Within a wide range around gated communities, the shapes of the discontinuities are rather complex and depend on the shape of census block boundaries. They nevertheless act as evidences of major discontinuities within a certain range from the walls, thus including some gated communities within a buffer zone.

\section{Social walls.}

According to the first factor, the most relevant discontinuities can be observed around the largest retirements communities (Leisure World, Casta del Sol, or Leisure Village in Ventura County), sustained by the joint effects of age, property values and White homogeneity. Partial discontinuities can also be observed along the walls (in Canyon Lake, or in the Palm Springs area). As a paradox, the ones that have long been popular and documented for being some prestigious enclaves do not produce strong discontinuities between themselves and their neighbors (Rolling Hills, Hidden Hills, Dove Canyon, Coto de Caza).

Although contrasts may appear at the threshold of the walls, the location of gated enclaves within a buffer zone is a common situation. In such cases, the discontinuities can be noticed within a certain distance from the wall, while the gated communities only produce weaker discontinuities. This may be observed at the Northeastern side of Dana Point, at the North side of Manhattan Village, in Newport Beach and Irvine (Big Canyon for instance), in Garden Grove, as well as in Camarillo, Calabasas and Hidden Hills (not mapped on figure 4).

Where discontinuities around a gated community and in the surrounding areas are both significant, gated enclaves are entrenched within a double boundary. This might be explained as a buffer zone protecting the gated community from a different neighborhood, as exemplified in Leisure World. The same method was also applied to the three other factors (although not mapped here), and it is relevant to mention that a buffer zone location usually 
occurs on several factors of social differentiation concurrently. Dana Point offers a good example: the major discontinuities observed on the first factor are linked to the municipal boundaries of Dana Point, whereas the major discontinuities observed on factor 2 and 4 (life cycle and age) relate to the gated communities boundaries of Niguel Shores and Bear Brand Estates.

Some gated communities play a role building local social enclaves, as retirement gated communities do, but others are integrated within a larger homogeneous territory. Finally, the respective roles of gated communities and their vicinities in building local discontinuities shall be evaluated.

\section{Segregation factors affected by the enclosure}

Table 1 compares the statistical distributions of dissimilarities among the different clusters in the three samples: at the level of large gated communities boundaries (308 segments), at the level of gated communities' vicinities (6,349 segments), and within the seven counties in southern California (33,800 segments).

\section{< INSERT TABLE 1 ABOUT HERE $>$}

Table 1. Level of discontinuities observed on the first factor, in the three vicinity levels.

The impact of gating is significant on factors 1,2 and 4: major discontinuities are more frequent at the gated communities level than in the vicinity (level 2) or in the remainder of Los Angeles area (level 3). On factor 1, $16.8 \%$ of the discontinuities rise above the 2 standard deviations threshold, and only $5.5 \%$ in the urban region and $8.9 \%$ in the vicinity's of gated communities. The proportions for factors 2 and 4 are also consistent with the hypothesis of an increase of the segregation level where gates and walls are erected. 
From these results, the relative increase of segregation can also be evaluated: a comparison of dissimilarity indices means shows a higher level of discrepancy at the gates threshold. The dissimilarities average associated with a gated community on factor 1 is 1.4 times higher than in the remainder of the urban area, 1.5 times higher on factor 2, and 2.7 times higher on factor 4. Such a contribution of life-cycle and age-based factors in the explanation of the impact of gating, though not surprising, reveals that living in a gated community is connected with age characteristics, and age homogeneity. This constitutes one of the most important factors of the social integration of those who choose to live in a gated community. And this is not specific to retirement communities: everything being equal regarding the other characteristics, age seems to affect a large majority of gated enclaves as a criterion for differentiation.

\section{Local buffer zones and location utility}

Beyond the empirical evidences of a local increase of segregation spatially associated with walls and gates, it seems surprising that gated communities are not associated with race segregation. They are spatially associated with an effect twice less important on factor 3 , than in the whole urban region: the average dissimilarity at level 1 is 0.259 , whereas the average dissimilarity observed at level 2 is 0.480 , and 0.504 at level of the urban region (Level 3). Though a paradox when considering the hypothesis usually developed about gated communities, this is demonstrated by factor 3: $95.8 \%$ of gated enclaves are not associated with discontinuities based on ethnicity above the threshold of one standard deviation.

Considering the ethnic status alone, gated communities indeed always locate within very homogeneous neighborhoods, and discriminate from their adjacent communities on the basis of age and economic status. The location within a buffer zone is not incidental, but rationally 
promoted by the developers choosing locations within an environment protected from the deterrent effects of ethnical diversity for the prospective buyers. This clearly affects gated communities, as far as they have to be distinctive housing for discriminating buyers concerned with the safety of their home, the security of their real-estate investment, and the social control of the urban setting. While protecting the economic value and the age-based homogeneity of the gated enclave, gated communities maximize ethnic location utility, being settled within some homogenate ethnic environments acting as a buffer zone.

\section{The structure of exclusion around gated communities}

A last step consists in a clustering the dissimilarities observed on the 4 factors provided by the multivariate analysis, in order to sort out the different types of discontinuities associated with large gated communities. The underlying assumption relies on the fact that a discontinuity may occur on one factor only, or concurrently on several factors. The second possibility clearly indicates a strong structural social separation, which helps to specify the territorial identities and singularities of gated communities compared to their neighbors.

A hierarchical cluster analysis is based on the dissimilarity indices computed for 30 large gated enclaves at the level of the gated communities boundaries (level 1: their boundaries exactly match the census block group boundaries). The results are summarized in table 2 . The six clusters account for $78 \%$ of the total variability observed.

\section{< INSERT TABLE 2 ABOUT HERE $>$}

Table 2. Level of discontinuities observed on the first factor, in the three vicinity levels.

According to these results, the following types of territorial patterns can be characterized in gated communities: 
- Both clusters 1 and 2 define the retirement gated enclaves (Leisure World, Leisure Village, Casa del Sol...), as the most segregated form of exclusion based on the gating. The age and life cycle are not the only predominant factors of social separation compared to the immediate vicinity, but the effects of socio-economic patterns are determinant (clusters 1 and 2), as well as the ethnic separation itself (cluster 1).

- Although the single ethnic factor is of lesser importance to explain the differentiations patterns associated with gating, four large gated communities are nevertheless associated with an ethnic segregation pattern (cluster 3). The ethnic homogeneity criteria seems to be predominant in Bradbury, in Manhattan Village, especially on its Northeastern side, where it makes contact with a more heterogeneous neighborhood, and also in Mar Vista Gardens (Culver city), a gated public housing community where Hispanics are predominant, and which was gated according to a city security policy.

- A majority of gated enclaves produce a complex layout of discontinuities (cluster 4 and 5). They significantly differ from their neighbors by their socio-economic structure and the age factor (average profile). They nevertheless share boundaries with several adjacent gated communities, indeed producing a mosaic social landscape. This is true especially in Dana Point where nine major gated communities are adjacent to each other (and also in the Palm Springs area): all are rather homogenous gated enclaves and they differentiate from each others. Complex patterns also appear in older neighborhoods like Hidden Hills or in Rolling Hills. Hidden Hills presents an interesting case. On the eastern edge, it shares a boundary with the city of Los Angeles and the discontinuity is close to the average profile (cluster 5); on its southern boundary with the city of Calabasas the discontinuity is based on ethnical 
differentiation (cluster 3); on its western edge no noticeable social discontinuity can be observed with the recent upper-scale gated enclave of Mountain Gate.

- Some gated communities do not differentiate more than the average profile, and are almost integrated with their environment (cluster 5), like Canyon Lake, Dove Canyon and Coto de Caza (Figure 5). An interesting case indeed: in 2000, while Dove Canyon was incorporating with the rest of the city of Rancho Santa Margarita, Coto residents opted out of the incorporation on the argument they have different socio-economic profiles (Ragland, 1999; Tessler, Reyes, 1999). It is always interesting to compare what gated communities residents think of themselves, as it is highly connected with a snob value and a subjective "distinction", although there is no socio-economic distinctive patterns outlined by a consistent discontinuity (Figure 5).

- A last group includes the large gated communities where no major discontinuity (cluster 6) can be observed (Canyon View Estates in Santa Clarita and Big Canyon in Irvine): in these two cases, the gate does not separate different social groups and only emphasizes the private property and the exclusiveness of the amenities.

The typology highlights the variety of the insertion of gated communities within their neighborhoods. The five categories of gated communities demonstrate that gates and walls contribute to the spatial integration of social territories. The statistical significance of the phenomena (although some bias were discussed) act as evidences of the construction of gated communities as homogeneous and differentiated territorial systems that intensify segregation at a local scope. These results are of interest because they better qualify the nuances occurring in segregation patterns where gated communities are present. First, the effect of age quite always determines the singularity of gated communities compared to their local surroundings, even for gated communities that are not retirement communities. This might suggest that 
middle-aged people and seniors are both attracted by the developers' discourses about security and their willingness as homeowners to protect a lifetime investment, and gated communities are an efficient answer to those concerns. Second, the combine effects of property values and socio-economic structure of population (factor 1) suggest that the homeowners usually consent to a higher level of investment in gated neighborhoods than in open neighborhoods in the surrounding. Finally, the effect of ethnicity must be analyzed carefully: it does not contribute at all to define gated communities as "worlds apart", except in a few cases like Bradbury, Manhattan Village. Nevertheless, gated communities quite always locate within homogeneous areas (on ethnic criteria) that act as buffer zones protecting the enclave from heterogeneous neighborhoods by a thick "wall of ethnic homogeneity". As a matter of fact, the municipalities where gated communities are settled often fit the limits of this "buffer zone" of homogeneous people. Gated communities stress an exclusion that is also structured by public policies at a municipal scale.

\section{Conclusion}

The analysis of gated communities as territorial systems defined by a physical and juridical border is of interest to comprehend their local impact and the spillover effects they might produce because of their numerous interactions with local governments and the social environment.

First, this focus highlights the originality of gated communities in the suburban development, that depends on the enclosure rather than on an architectural singularity of the neighborhood itself. A gated community is nothing else but a Common Interest Development, and often looks like some other neighborhoods in the surroundings. Nevertheless, the enclosure favors the property value and increases the property tax basis. Furthermore, the erection of gates 
transfers the cost of maintaining the urban infrastructure to the association and the homeowner. The relationships between the gated enclaves and the public authorities can be thus summarized: because of the fiscal basis they produce, at almost no cost except general infrastructures (freeways and other major infrastructures), gated communities are particularly desirable for local governments. The sprawl of gated communities is not to be understood as a trend towards a "secession" from the public authority but as a public-private partnership, a local game where the gated community has a financial utility for the public authority, whilst the property owners association is granted more autonomy in local governance, as discussed in the case of Calabasas (for critical material regarding this issue, see also Le Goix, 2003). This ambiguous relation helps to get a better understanding of the reasons leading to a sprawl of gated communities that cannot be simply explained by a rush for security.

Second, the analysis seeks to demonstrate how the gated territorial construction produces spillover effects. Not only gated communities probably divert crime and protect property values (with a deterrent effect for property values in the surroundings), but it was possible to measure the socio-economic effects of this structuring of urban space at a local scale: gated communities are homogeneous territories that differentiate from their neighbors especially on age criteria and socio-economic status. A last conclusion highlights the strategies of developers: gated communities are often located within a buffer zone of homogeneous ethnic patterns, and these buffer zones often fit the municipal boundaries. Gated communities do not increase segregation on their own. They belong to a process of production of urban space made by private strategies (the developers) and public strategies (attracting tax-payers) which is finally consistent with the long involvement of public policies with segregation processes, as Massey and Denton (1993) pointed it out in the United Sates. The diffusion of gated communities is not only supported by developers and home-building industries, but also by public authorities earning their share in the process. 


\section{Acknowledgments}

This paper is drawn from a doctoral thesis founded by the CNRS (UMR Géographie-cités 8504, Paris), the French-American Foundation (Tocqueville Fellowship, 2000-01), and the French-American Commission (Fulbright Research Scholarship, 2002-03), which is gratefully acknowledged. I also sincerely wish to thank Pr. Allen J. Scott (UCLA) and Pr. Setha Low (CUNY) for their advices, comments and corrections of earlier version of this paper.

\section{References}

APPARICIO P. (2000) Indices of residential segregation: an tool integrated in geographical information system.

Cybergeo 134 (http://cybergeo.presse.fr).

BATOR F. M. (1958) The anatomy of market failure. Quarterly Journal of Economics, 72, pp. 351-379.

BIBLE D. S. and HSIEH C. (2001) Gated Communities and Residential Property Values. Appraisal Journal, 69 (2), p. 140.

BLAKELY E. J. and SNYDER M. G. (1997) Fortress America, Gated Communities In The United States. Washington D.C., Cambridge, M.A.: Brookings Institution Press \& Lincoln Institute of Land Policy.

BROWN K. (1991) Mello-Roos Financing in California. Sacramento, CA: State of California, California Debt Advisory Commission.

BRUNET R. (1965) Les phénomènes de discontinuité en géographie. Paris: Editions du CNRS (2ème édition, 1970).

CALDEIRA T. P. R. (2000) City of Walls: Crime, Segregation, and Citizenship in Sao Paulo. Berkeley, CA: University of California Press.

CASTELLS M. (1983) The City and the Grassroots. Berkeley, CA: University of California Press.

CIOTTI P. (1992) Forbidden city. Los Angeles Times; Los Angeles; February 9, 1992, p. B3.

CURTIN D. J. (2000) California Land-use and Planning Law, 2000: Solano Press Book.

DAVIS M. (1990) City of Quartz, Excavating the Future of Los Angeles. London: Verso (coll. The Haymarket Series).

DAVIS M. (1998) Ecology of Fear: Los Angeles and the imagination of disaster. New York: H. Holt.

DEAR M. and FLUSTY S. (1998) Postmodern urbanism. Annals of the Association of American geographers, 88 (January 1998), pp. 50-72.

DECROLY J. M. and GRASLAND C. (1992) Frontières, systèmes politiques et fécondité en Europe. Espace, Populations et Sociétés (2), pp. 135-152.

DONZELOT J. (1999) La nouvelle question urbaine. Esprit (258), pp. 87-114.

DONZELOT J. and MONGIN O. (1999) De la question sociale à la question urbaine. Esprit (258), pp. 83-86.

FLUSTY S. (1994) Building Paranoia: The Proliferation of Interdictory Space and the Erosion of Spatial Justice. West Hollywood, CA: Los Angeles Forum for Architecture and Urban Design.

FOLDVARY F. (1994) Public Goods and Private Communities: the Market Provision of Social Services. 
Aldershot: Edward Elgar.

FORSYTH A. (2002) Who Built Irvine? Private Planning and the Federal Government. Urban Studies, 39 (13), pp. 2507-2530.

FOX-GOTHAM K. (2000) Urban Space, Restrictive Covenants and the Origins of Racial Segregation in a US city, 1900-50. International Journal of Urban and Regional Research, 24 (3), pp. 616-633.

FRANCOIS J.-C. (1995) Discontinuités dans la ville. L'Espace des collèges de l'agglomération parisienne (1982-1992). Doctorate thesis, geography, Université Paris 1 - Panthéon - Sorbonne.

FREY W. H. (1993) The New Urban Revival in the United-States. Urban Studies, 30 (4/5), pp. 741-774.

GARREAU J. (1991) Edge City : Life on the New Frontier. New York: Doubleday.

GLASZE G., FRANTZ K. and WEBSTER C. J. (2002) The global spread of gated communities. Environment and Planning B: Planning and Design, 29 (3), pp. 315-320.

GRASLAND C. (1992) Analyse des couples de lieux et modélisation en géographie. Géopoint 1992, Université d'Avignon, Groupe Dupont, pp. 97-105.

GRASLAND C. (1997) L'analyse des discontinuités territoriales. L'exemple de la structure par âge des régions européennes vers 1980. L'Espace Géographique, 26 (4), pp. 309-326.

HELSLEY R. W. and STRANGE W. C. (1999) Gated Communities and the Economic Geography of Crime. Journal of Urban Economics (46), pp. 80-105.

JACKSON K. T. (1985) Crabgrass Frontier; The Suburbanization of the United States. Oxford: Oxford University Press.

JAILLET M.-C. (1999) Peut-on parler de sécession urbaine à propos des villes européennes ? Esprit, 11 (258, Novembre 1999), pp. 145 - 167.

KAZMIN A. L. (1991) 5 Coucil Memebers are sworn in as Calabasas marks debut as a city. Los Angeles Times; Los Angeles, CA; April 6, 1991; Metro, part B, p.4.

KAZMIN A. L. (1991) Calabasas Cityhood appears a certainty. Los Angeles Times; Los Angeles, CA; February 24, 1991; Metro, part B, p. 3.

KENNEDY D. J. (1995) Residential Associations as State Actors : Regulating the Impact of Gated Communities on Nonmembers. Yale Law Journal, 105 (3), décembre 1995.

KNOX N. H. and KNOX C. E., Eds. (1997) California General Plan Glossary: California Planning Roundtable, the Governor's Office of Planning and Research.

LACOUR-LiTTlE M. and MALPEZZI S. (2001) Gated Communities and Property Values. Madison, WI: Wells Fargo Home Mortgage and Department of Real Estate and Urban Land Economics - University of Wisconsin.

LE GOIX R. (2001) Les "communautés fermées" dans les villes des Etats - Unis : les aspects géographiques d'une sécession urbaine. L'Espace Géographique, 30 (1), pp. 81-93.

LE GOIX R. (2002) Les gated communities en Californie du Sud, un produit immobilier pas tout à fait comme les autres. L'Espace Géographique, 31 (4), pp. 328-344.

LE GOIX R. (2003) Les "gated communities" aux Etats-Unis, morceaux de villes ou territories à part entière ? (Gated communities within the cities in the US: Urban neighborhoods or territories apart?). Doctorate thesis, Geography, Université Paris Panthéon-Sorbonne (http://tel.ccsd.cnrs.fr/documents/archives0/00/00/41/41/index_fr.html) 
LOW S. M. (2001) The Edge and the Center: Gated Communities and the Discourse of Urban Fear. American Anthropologist, 103 (1), p. 45.

MARCUSE P. (1997) The Ghetto of Exclusion and the Fortified Enclave: New Patterns in the United States. The American Behavioral Scientist (41), pp. 311-326.

MASSEY D. S. and DENTON N. A. (1993) American apartheid: segregation and the making of the underclass. Cambridge, Mass.: Harvard University Press.

MCKENZIE E. (1994) Privatopia: Homeowner Associations and the Rise of Residential Private Government. New Haven (Conn.) ; London: Yale University Press.

MILLER G. J. (1981) Cities by Contract. Cambridge, Ma.: The MIT Press.

MOORE M. (1995) Brentwood Road Block Communities: Residents of enclave near the Getty Center receive tentative City Council approval to erect gates. Los Angeles Times; Los Angeles; May 18, 1995, p. 3.

MOORE M. (1995) Part of Brentwood Allowed to Become Gated Community. Los Angeles Times, Home Edition; Los Angeles; June 4, 1995, p. 3.

NGUYEN T. (1999) Coto de Caza Residents Say No to School Within Gates. Los Angeles Times, Orange County Edition; Los Angeles; March 4, 1999; Sect. B, p. 1.

POOL B. (1987) Calabasas cityhood backers dealt another major setback. Los Angeles Times, 1; Los Angeles, CA; May 1, 1987; Metro, part 2, p. 6.

POOL B. (1987) Calabasas cityhood bid falters again; 3 residential areas, industrial park omitted; new finance study ordered. Los Angeles Times, Valley Edition; Los Angeles, CA; April 6, 1991; Metro, part 2, p. 10.

POOL B. (1987) Mountains or Molehills? Calabasas cityhood backers contest builder's right to exclude 1,300 acres of ranchland. Los Angeles Times; Los Angeles, CA; August 29, 1987; Metro, part 2, p. 6.

PURCELL M. (1997) Ruling Los Angeles : Neighborhood movements, Urban Regimes, and the Production of Space in southern California. Urban Geography, 18 (8), pp. 684-704.

REICH R. B. (1991) Secession of the Successfull. New-York Times Magazine, p. 16.

SANCHEZ T., LANG R. E. and DHAVALE D. (2003) Security versus Status? A First look at the Census's Gated Communities data. Alexandria, VA: Metropolitan Institute, Virginia Tech. 19 p.

SCOTT A. J. (1980) The urban land nexus and the State. London: Pion.

STARK A. (1998) America, the Gated ? (Impact of Gated Communities in Political Life). Wilson Quaterly, 22 (1), pp.50-58.

SORKIN M. (1992) Variations on a Theme Park: The New American City and the End of Public Space. New York: Hill and Wang.

WEBSTER C. J. (2002) Property Rights and the Public Realm: Gates, Green Belts, and Gemeinschaft. Environment and Planning B: Planning and Design, 29 (3), pp. 397-412. 
Table 1. Level of discontinuities observed on the first factor, in the three vicinity levels.

\begin{tabular}{|c|c|c|c|c|c|c|}
\hline & \multicolumn{4}{|c|}{ Frequency* of discontinuities ( \%) } & \multicolumn{2}{|c|}{ Sample parameters } \\
\hline & $\varnothing$ & + & ++ & +++ & Mean & Std. Dev. \\
\hline \multicolumn{7}{|c|}{ Factor 1 : socio-economic structure associated with race and age. } \\
\hline Level 1 : Gated communities boundaries & 65,3 & 17,9 & 11,0 & 5,8 & 1.495 & 1.660 \\
\hline Level 2 : In the vicinity & 71,5 & 19,7 & 5,7 & 3,2 & 1.236 & 1.249 \\
\hline Level 3 : In southern California & 76,4 & 18,0 & 3,9 & 1,6 & 1.057 & 1.076 \\
\hline \multicolumn{7}{|l|}{ Factor 2 : Life-cycle. } \\
\hline Level 1 : Gated communities boundaries & 66,9 & 14,6 & 9,7 & 8,8 & 1.060 & 1.216 \\
\hline Level 2 : In the vicinity & 74,1 & 18,2 & 5,4 & 2,3 & .794 & .834 \\
\hline Level 3 : In southern California & 78,7 & 15,3 & 4,0 & 1,9 & .710 & .782 \\
\hline \multicolumn{7}{|c|}{ Factor 3 : Ethnic segregation effect, regardless of social status. } \\
\hline Level 1 : Gated communities boundaries & 95,8 & 4,2 & 0,0 & 0,0 & .259 & .230 \\
\hline Level $2:$ In the vicinity & 85,0 & 11,3 & 2,3 & 1,5 & .480 & .712 \\
\hline Level 3 : In southern California & 82,4 & 13,2 & 2,8 & 1,5 & .504 & .656 \\
\hline \multicolumn{7}{|c|}{ Factor 4: Age effect, regardless of social status. } \\
\hline Level 1 : Gated communities boundaries & 60,4 & 17,5 & 4,5 & 17,5 & 1.770 & 2.318 \\
\hline Level $2:$ In the vicinity & 76,2 & 15,7 & 4,0 & 4,1 & .874 & 1.122 \\
\hline Level 3 : In southern California & 83,7 & 11,6 & 2,6 & 2,2 & .662 & .890 \\
\hline
\end{tabular}

Distribution are clustered according to mean and standard deviation of the Level 3 (33800 segments).

Abs. values of dissimilarity indices $: \varnothing: \leq 1$ std. dev.; + :1-2 std. dev.;

$++: 2-3$ std. dev.; +++ : $\geq 3$ std. dev.

Sources : US Census 2000, block groups files SF1-SF3, database Gated Communities

UMR Géographie Cités 8504, 2002. 
Table 2. Cluster analysis of the dissimilarities

observed between the gated communities and their immediate vicinities

(Hierarchical clustering, 308 spatial units, 6 clusters and $78 \%$ of variability explained).

\begin{tabular}{|c|c|c|c|c|c|}
\hline \multirow[b]{2}{*}{ Cluster (and tree) } & \multirow[b]{2}{*}{ Freq. } & \multicolumn{4}{|c|}{$\begin{array}{c}\text { Contribution of the variables (dissimilarities observed for each } \\
\text { factor) }\end{array}$} \\
\hline & & $\begin{array}{l}\text { Factor 1: } \\
\text { socio-economic } \\
\text { structure } \\
\text { associated with } \\
\text { race and age. }\end{array}$ & $\begin{array}{l}\text { Factor 2: } \\
\text { Life-cycle. }\end{array}$ & $\begin{array}{l}\text { Factor 3: } \\
\text { Ethnic } \\
\text { segregation, } \\
\text { regardless of } \\
\text { social status. }\end{array}$ & $\begin{array}{l}\text { Factor } 4: \\
\text { Age effect, } \\
\text { regardless of } \\
\text { social status. }\end{array}$ \\
\hline $\begin{array}{l}\text { 1. Complete territorial } \\
\text { discontinuity on all } \\
\text { the factors. }\end{array}$ & $1.6 \%$ & +++ & +++ & ++ & +++ \\
\hline $\begin{array}{l}\text { 2. Retirement } \\
\text { enclaves with ethnic } \\
\text { homogeneity. }\end{array}$ & $15.3 \%$ & ++ & ++ & & ++ \\
\hline $\begin{array}{l}\text { 3. Enclaves based on } \\
\text { ethnic discontinuity. }\end{array}$ & $14.6 \%$ & & & ++ & \\
\hline $\begin{array}{l}\text { 4. Enclaves similar to } \\
\text { the average profile. }\end{array}$ & $33.1 \%$ & & $(+)$ & $(-)$ & \\
\hline $\begin{array}{l}\text { 5. Enclaves below the } \\
\text { average profile. }\end{array}$ & $24.0 \%$ & $(-)$ & $(-)$ & & $(-)$ \\
\hline $\begin{array}{l}\text { 6. Poorly defined } \\
\text { discontinuities. }\end{array}$ & $11.4 \%$ & - & - & - & - \\
\hline $\begin{array}{l}\text { Average profile } \\
\text { Compared to the discontinuities } \\
\text { observed in the whole Los Angel } \\
\text { the gated communities are locall } \\
\text { associated with an average } \\
\text { discontinuity... }\end{array}$ & $\begin{array}{l}\text { es area, } \\
\text { ly }\end{array}$ & 1.4 times higher & 1.5 times higher & 2 times less & $\begin{array}{l}2.7 \text { times } \\
\text { higher }\end{array}$ \\
\hline
\end{tabular}

+/- : contribution $\geq+/-0,5$ sdt. dev; ++/- - : contribution $\geq 1$ std. dev.; +++/- - - : contribution $\geq 2$ std. dev.

$(+)$ et $(-)$ : low contribution $<0,5$ std. dev.

Sources : US Census 2000, database Gated Communities UMR Geographie-cités. 


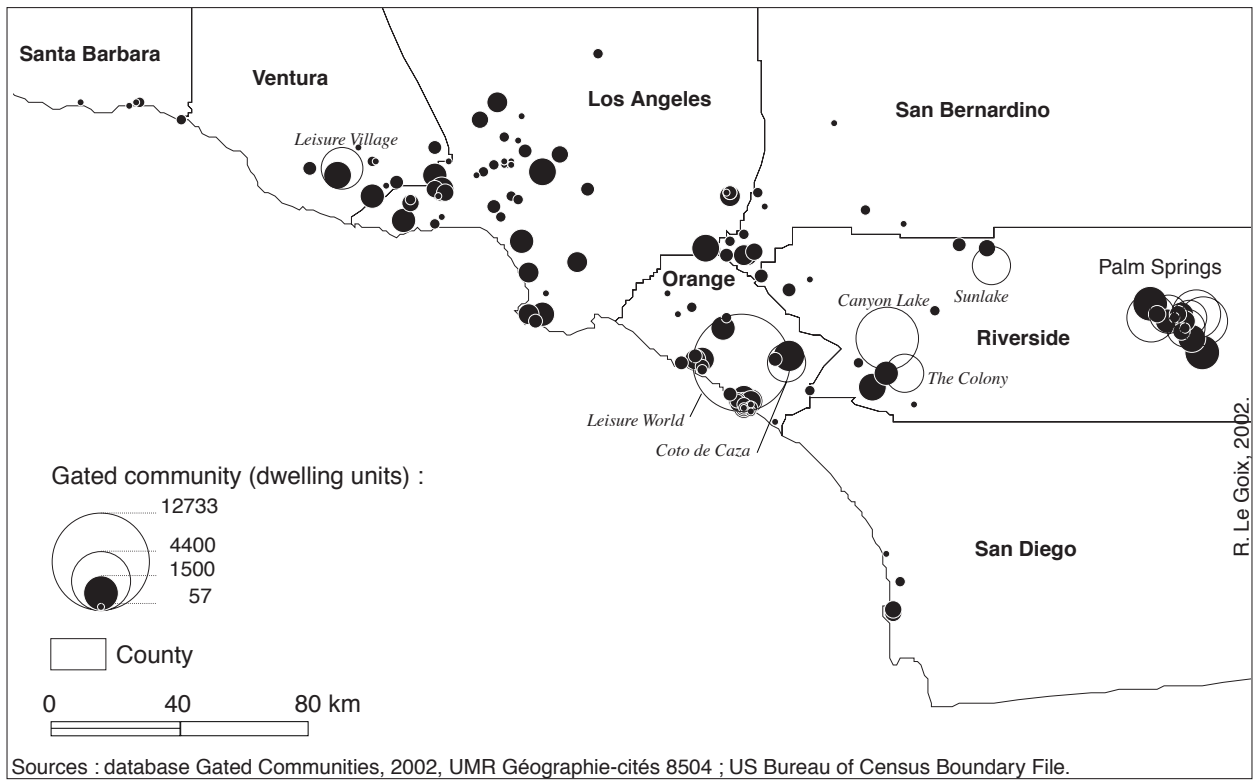

Figure 1. The size of gated communities in southern California.

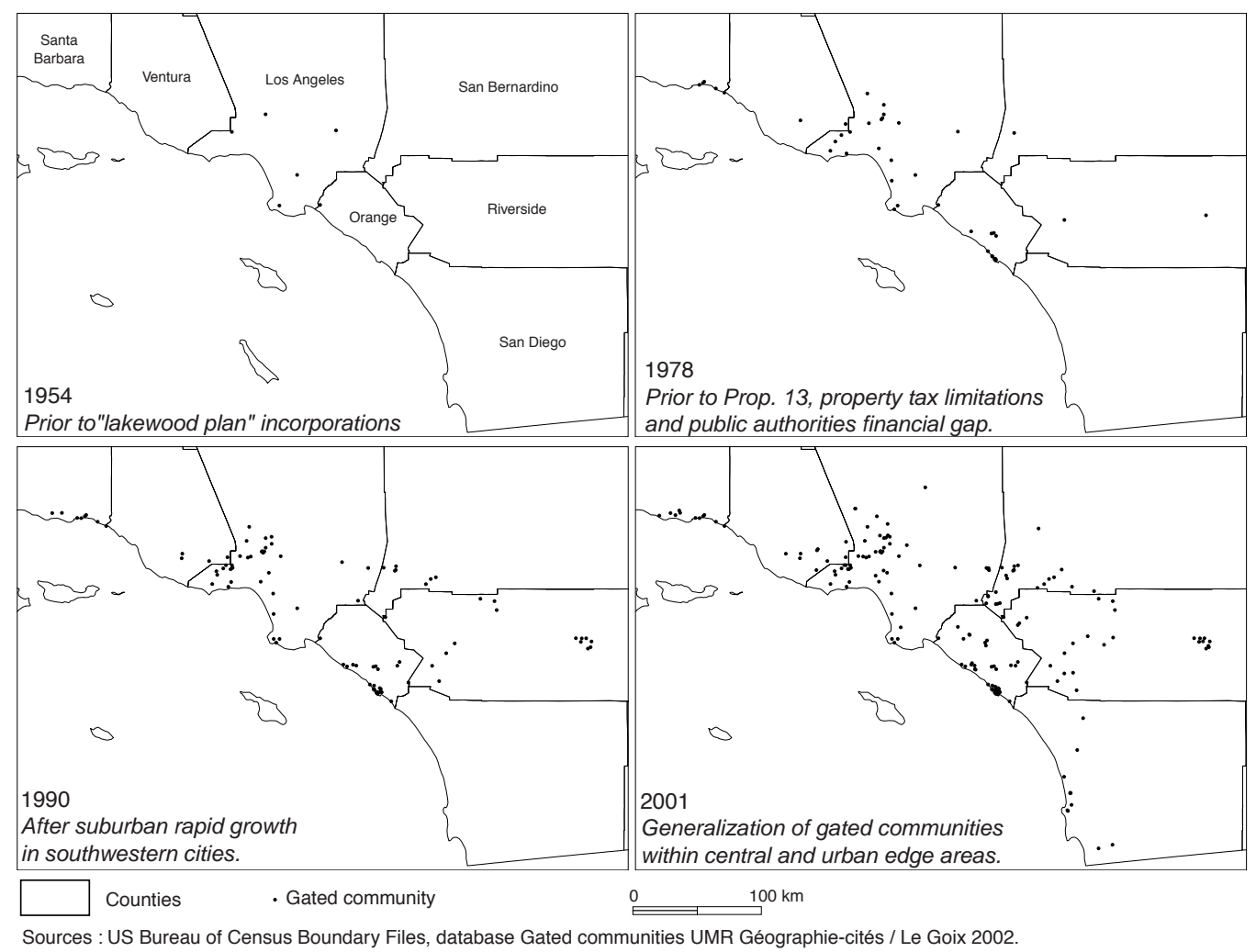

Figure 2. The diffusion of gated communities in southern California. 


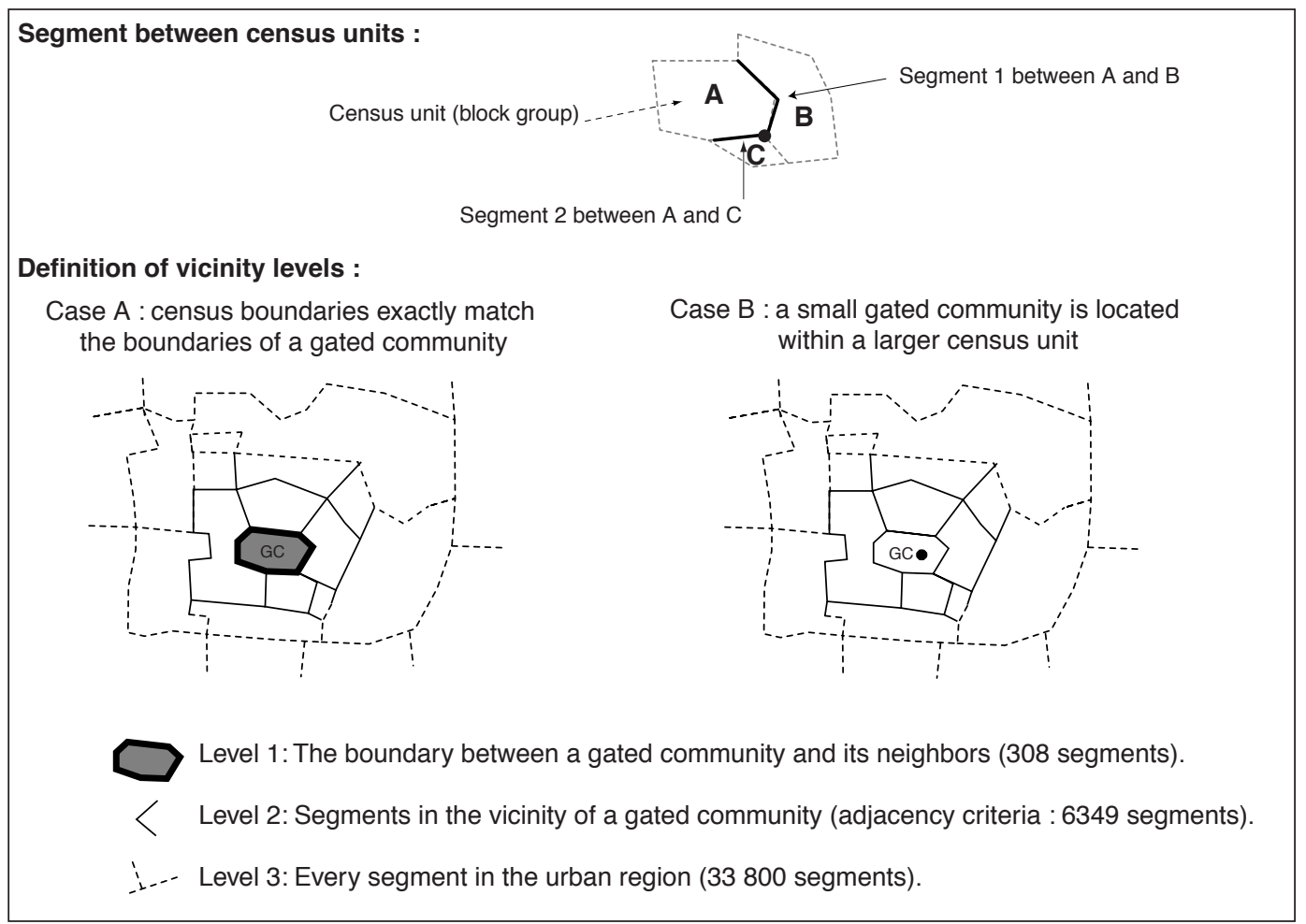

Figure 3. Three vicinity levels around gated communities.

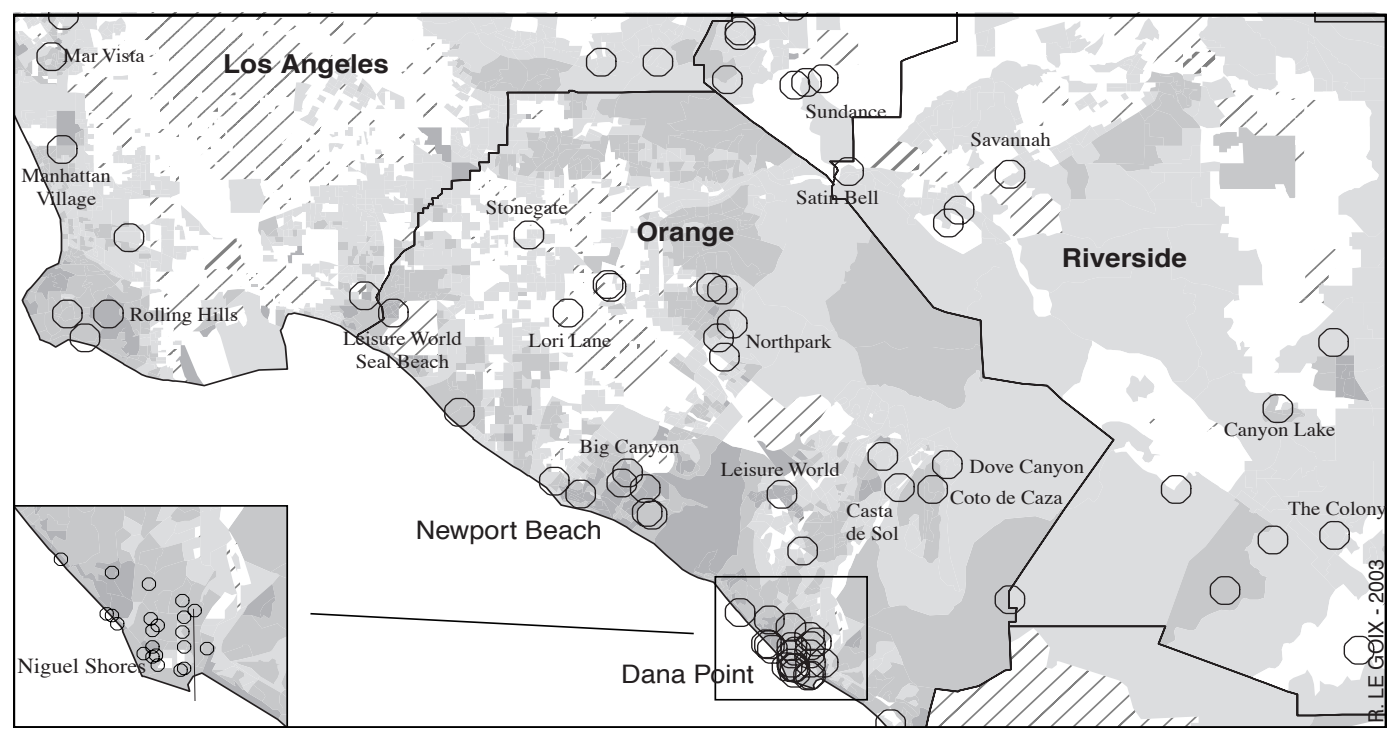

Factor analysis of 12,549 census bock groups. Block groups position on the first factor axis (33.5\% of the variability) :

Gated community
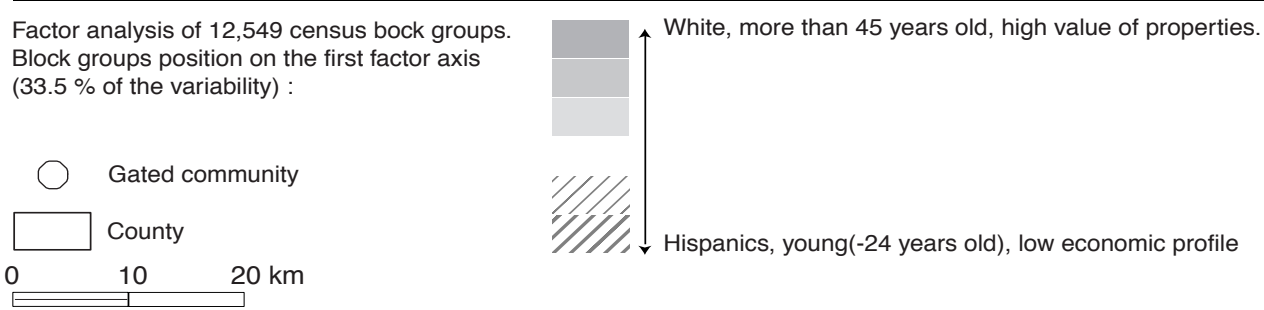

Sources : US Bureau of Census 2000 (SF1, SF3). Census Boundary Files. Database Gated Communities UMR Géographie-Cités.

Figure 4. Gated communities and the first socio-economic factor of segregation (South Los Angeles, Orange county and west Riverside county). 


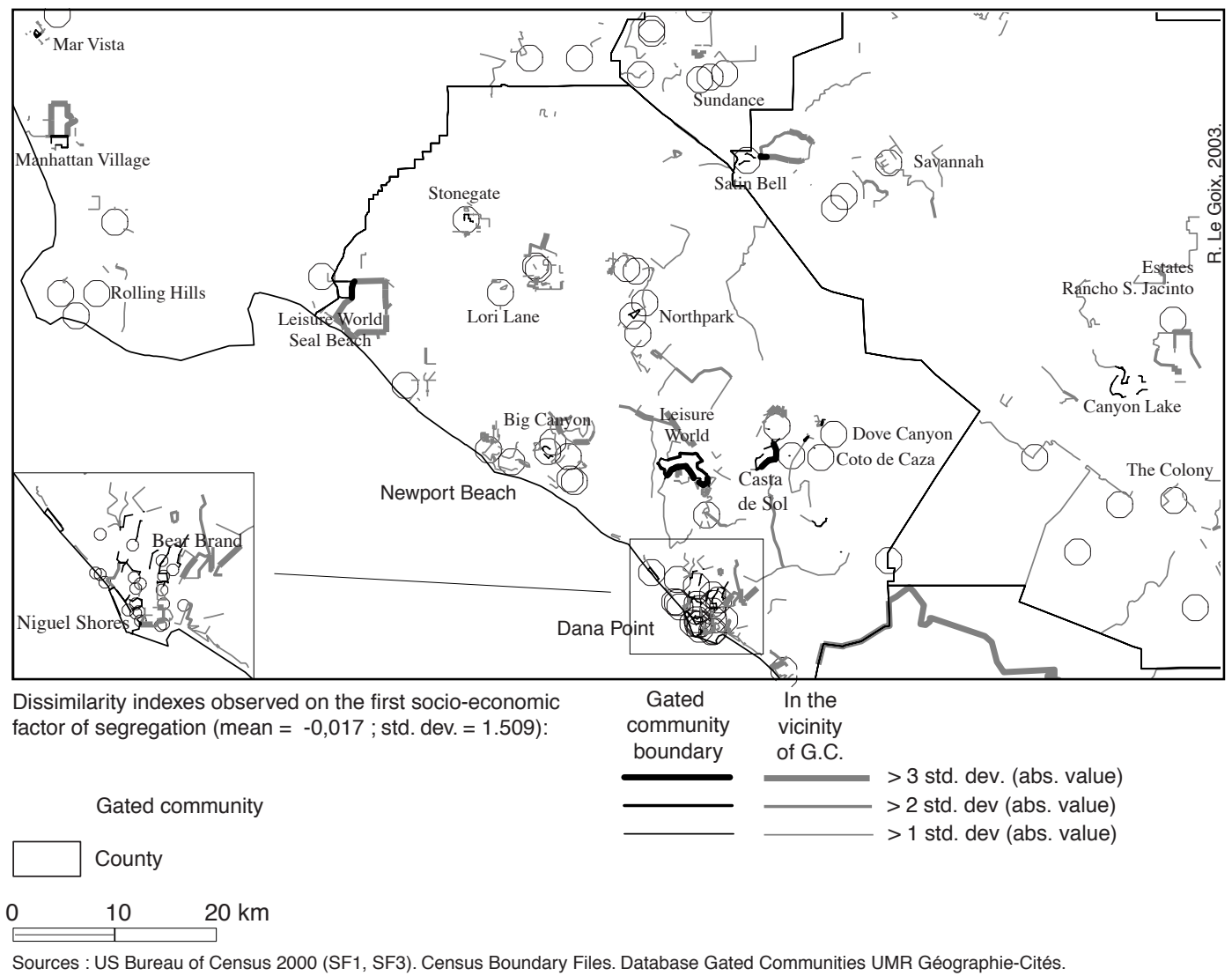

Figure 5. Major socio-economic discontinuities occuring in gated communities' vicinities. (South Los Angeles, Orange county and West Riverside county). 